inOfedia $\quad \begin{aligned} & \text { InMedia } \\ & \text { The French Journal of Media Studies }\end{aligned}$

6 | 2017

Fields of Dreams and Messages

\title{
Coubertin's Music: Culture, Class, and the Failure of the Olympic Project
}

Nicholas Attfield

\section{(2) OpenEdition \\ Journals}

Electronic version

URL: http://journals.openedition.org/inmedia/934

ISSN: 2259-4728

Publisher

Center for Research on the English-Speaking World (CREW)

Electronic reference

Nicholas Attfield, «Coubertin's Music: Culture, Class, and the Failure of the Olympic Project », InMedia [Online], 6 | 2017, Online since 18 December 2017, connection on 08 September 2020. URL : http:// journals.openedition.org/inmedia/934

This text was automatically generated on 8 September 2020

(c) InMedia 


\title{
Coubertin's Music: Culture, Class, and the Failure of the Olympic Project
}

\author{
Nicholas Attfield
}

1 In an article for the Research Quarterly for Exercise and Sport in 1996, Douglas A. Brown presented a distinctive model for addressing the subject of aesthetics at the Olympic Games. According to this model, the modern Games' founder, Baron Pierre de Coubertin, had used existing aesthetic theory, and the aesthetic ideas he derived from it, as a means of articulating his vision of sport as a signifying cultural practice. ${ }^{1}$ Sport, Coubertin wrote in an essay of 1922, ought to be recognised as both the producer of and the inspiration for art; in turning the athlete into a "living sculpture", it was a source of beauty to be consecrated and celebrated in spectacles and festivals. ${ }^{2}$ As the last claim begins to imply, Coubertin's aesthetics of sport was intended to fuse productively with the broader socio-political ideology of his Olympism, itself a philosophy of life uniting body, mind, and will. In coming together to contemplate the sporting body, his Olympic audiences would grasp their universal humanity and the values that they shared - a luminous gift bestowed by the ancient world upon the contemporary one.

2 At first glance, it is perhaps all too easy to assess Coubertin (1863-1937) as a stuffy and rather conservative French aristocrat of the Third Republic, a devoted fan of English public schools and the privileged lifestyle that went with such an education. Yet part of the great value of Brown's approach is its tantalizing hint of this as a distorting image. One of Coubertin's specific aesthetic ideas is shown, for example, to be that of eurhythmy (l'eurhythmie), an entrancing form of beauty that arises from the experience of diverse and simultaneous events. For Coubertin, eurhythmy was apparently no preserve of the highly cultured few, but rather an experience more accessible to the stadium-bound masses, precisely because these latter were better attuned to the perception of large ensembles as opposed to fine details. Its creation depended, moreover, not only on events unfolding at the same time, but also on the reflexive 
presence of the spectator observing them - who thus became both subject and object of the overall experience.

3 In short, Brown proposes that Coubertin's eurhythmy be understood as a specifically modern form of beauty, one that casts a critical glance towards the conventional aesthetics of the fine arts. In experimenting with it in practice - both at the fêtes sportives (sporting festivals) linked to motivating Olympic Congresses and at the early Games themselves - Coubertin showed himself to be a kind of modernist, in the sense that he poised antithetical concepts of popular and high culture dialectically against one another and, in so doing, advanced his olympism as a movement for the transformation of society and culture. This might begin in his contemporary France but, with the gradual transmission of the Games around the globe, it was intended to spread far beyond its initial bounds. ${ }^{3}$

4 I set this model out so that, in the present article, I might pursue and develop some of the tensions and ellipses inherent within it. Chief among these are the problem of social class and its attendant tastes and cultural forms. After all, Coubertin's early aesthetic experiments were theorized within the pages of the Revue Olympique, a specialist periodical with minimal circulation; they were subsequently premiered before (and heartily approved by) small groups of donors and those who would become the inaugural membership of the International Olympic Committee (IOC). At the very most, in other words, we might speak of only a few hundred people as engaged in the projects of early Olympism, and we might add that many of these were drawn from the same background of affluence, privilege, and French cultural republicanism as Coubertin himself. For all their modern overtures to the masses and claims to populism, then, aesthetic ideas like eurhythmy were developed and delivered within something of a narrow social and cultural milieu. These were origins that, in Coubertin's rather patronising and patriarchal view, placed them above the organisational skills and imaginative grasp of the National Olympic Committees - and, in turn, drove him to despair of the failure of his Olympic project as the nascent Games became fully fledged internationally in the early years of the twentieth century.

5 My central claim in this article is that this trajectory towards failure can be brought to especially sharp focus by considering the subject of music in Coubertin's thought and practice. Thus, scrutiny of Olympic music can give us insights into the politics of spectator sport in one of its most prominent modern arenas. Of course, in a sense, we have heard music sounding distantly behind many of Brown's presentations of Coubertin's work already: the very word "eurhythmy", for example, and all the good vibrations it implies; or the Théatre du Peuple (people's theatre) with which Coubertin is shown to have been well acquainted. ${ }^{4}$ Yet somehow it never emerges in full at the foreground of Brown's discussion. As I shall argue, however, there is plentiful evidence that it should: biographically speaking, for example, from Coubertin's memories of his upbringing, education, and concert-going; theoretically, from the remarks on music made by Coubertin and his colleagues in the pages of the Revue Olympique; and practically, from the many musical performances that these early Olympians organised in order to promote and deliver their revival of the Games.

6 We might add that, if eurhythmy is to be understood as an all-embracing aesthetic experience - one that draws the stadium crowd into the diverse events unfolding before it - then the wide sonic net cast by performed music, and its immediate emotional impact as an art form, make it the eurhythmic medium par excellence. 
Through music, it could be claimed, Coubertin attempted to make his Olympic humanism not only an enthralling spectacle, but also a resounding reality. If so, however, the class problem arises once again, and here with particular acuity. A significant part of music's impact, after all, is its powerful connotation of social class; the musical choices Coubertin made and dictated, and the hierarchy of taste they set out, again draw us back to the same failure that loomed over him when the Games took to the wider world stage.

7 To date, the literature on music at the Olympics has been somewhat chequered, and has rarely engaged these events' musical provision critically. William K. Guegold's compendium 100 Years of Olympic Music provides useful lists of the works played at opening and closing ceremonies from 1896 onwards and at supporting events during the Games; it is, however, strewn with errors and omissions and features little commentary on aesthetics and their place within Olympism. ${ }^{5}$ The special issue of the IOC-published Olympic Message (1996) is likewise selectively descriptive rather than critical. Elsewhere, focus has fallen on the history of the official Olympic Hymn and the Fine Arts competitions that took place (and in which medals could be won) from the Games in Stockholm in 1912 to those in London in 1948, but here, again, little has emerged beyond sketchy details of the largely forgotten composers and works entered in the music category, and of the panels that adjudicated them. ${ }^{6}$

Elizabeth Schlüssel's doctoral thesis (Cologne, 2001) is a remarkable exception to this state of research affairs, in that it provides a comprehensive survey of Olympic Summer Games ceremonial music from Athens in 1896 to Munich in 1972, and grounds this in a preceding discussion of late nineteenth-century reception and recreation of the music of antiquity. Yet its historical ambit across the twentieth century is so broad that, even at the considerable length of over 700 pages, attention inevitably veers rapidly away from Coubertin's formative ideas. Eurhythmy is, for example, only mentioned once. ${ }^{7}$ Similarly, Jeffrey O. Segrave's reading of Beethoven's Ninth Symphony as a "medium of ideology" that helps to maintain the cultural authority of the Olympic movement is a convincing account of a position that certainly originates in Coubertin's musicaesthetic thought, but hardly exhausts it in theory or as it was put into practice in the early years of the twentieth century. ${ }^{8}$

9 The present article, then, begins from the claims made for music by Coubertin and his colleagues, specifically in their Romantic belief in its eurhythmic ability to unite and elevate an attentive people to the higher plain of humanity so valued by Olympism. Tracing Douglas Brown's 1996 approach, the article then traverses disciplinary boundaries, moving from an initial ground of the history of ideas towards that of modern cultural practice and production: it gives an analysis of musical experimentation amidst other artistic and sporting forms at Coubertin's initial fêtes sportives and related events, and the difficulties attendant on translating these to the early Games.

10 Yet if this is a means of bringing out the trajectory of failure noted above, then it is also a path to its apparent resolution. The Berlin Summer Games of 1936 at last presented the overjoyed Coubertin with a working paradigm for music and aesthetics within the Olympic movement. By the same token, however, these Games steered towards a collision with twentieth-century national politics. Here, where the Olympic message of peace threatened to merge into the National Socialist mobilization for war, he likely realised that his festival aesthetics - in their visual, but also their sounding glory - had 
reached something of a final threshold, a place from which his Olympism, in the second half of the twentieth century, would ultimately have to retreat.

\section{The "Shock of the Beautiful"}

11 It would be no difficult task to show Coubertin as the bearer of utterly conventional musical tastes of the late nineteenth-century French upper classes. His memoirs of earliest childhood, for example, reveal his love of grand and spectacular national pageantry, both real and imagined, and the music heard within it. One of his very first memories recalls the Paris Exhibition of 1867 and the orchestras that played at the festooned Champs-de-Mars, while another recalls similar events at St. Peter's in Rome; recounting his school days, he writes of an invented capital city he named Agram and of sitting at the piano in order to compose 'rousing symphonies' that might lead its armies into battle. ${ }^{9}$

12 Many of his letters and essays, meanwhile, make clear his devotion to music of the established German canon, and indicate his share in the commonplace European nineteenth-century belief in German music as the utmost medium of humane universality. He cites, for example, pilgrimages made with his wife to hear Wagner's music-dramas and emphasizes a love of Beethoven - in particular the choral finale of the Ninth Symphony and its setting of Schiller's "Ode to Joy". His fascination with ancient culture, moreover, is reflected by his devotion to the operas of Gluck and that composer's capacity to bring back "the melodious strains of the soul of antiquity." 10

Such musical tastes could, in a sense, be merged directly into Coubertin's Olympic revival project without the need for any mediating theory. When he writes (to cite only a couple of instances) of music and sport as "the most fruitful aids to reflection and clearer vision" and of Wagner's theatre at Bayreuth as a place where he could "examin[e] the Olympic horizons in peace", it is hard not to think of the resulting Games as a kind of Wagnerian Gesamtkunstwerk (total artwork) that sought to embed the sporting body within established cultural forms: the national, the ceremonial, the syncretic, the antique. ${ }^{11}$ Many have made precisely this connection. Indeed, Norbert Müller seems to stress it when, introducing Coubertin's collected writings, he remarks on the "small step" between Coubertin's "impressive creativity" and his passion for Wagner. ${ }^{12}$

Yet, the taking of such a direct step risks overlooking the subtlety of the theory that intervened: the constellation of ideas, in short, that linked such musical tastes to sport and the sporting body, to the ideology of olympism as a mass movement, and to idiosyncratic notions like eurhythmy. To gain a better sense of this constellation, we might begin by turning to the copious literature generated by the early Olympic movement in its various attempts at self-definition. Central here are articles and reports published in the Revue Olympique, the official journal of the International Olympic Committee. This first appeared between 1901 and 1914, and, in its many attempts to engage Olympism's sporting festivals with existing artistic and cultural discourses, has been called a "type of manifesto of aesthetic modernism". ${ }^{13}$

In May 1906, ten years after the first modern Games in Athens, Coubertin arranged a conference at the Comédie Française for the express purpose of discussing the role of the arts within Olympism. The report on "resolutions made" at this conference appeared the next month in the Revue; very likely written by Coubertin himself, this 
advanced a section on music, in which musical practices, quite unlike those of literature, were identified as promising a "direct support" (appui immédiat) for sporting ones..$^{14}$ Echoing a commonplace medical view of the time, it was here claimed that singing held benefits for respiratory development, and so the Committee had recommended that sports societies should join forces with local choral groups and introduce singing events, particularly en masse and en plein air. ${ }^{15}$ Moreover, numerous musically inclined members - amongst them the composers Max d'ollone, Henri Rabaud, Arthur Coquard, and Louis Bourgault-Ducoudray - were tasked with identifying appropriate repertoire (both "ancient and modern") to be sung by these societies, and to challenge composers to write new "odes and cantatas in honour of athleticism and sport." With its alternation of choral sections and militaristic fanfares, Spyridon Samaras's Olympic Hymn (written for the 1896 Games) is identified as a worthy model for such new composition. ${ }^{16}$ This, then, might stand as the first work of Olympic Music.

Yet, crucially, there was far more at stake here than a matter of respiratory gain through singing - that is, far more than the matter of an applied practice for athletes but something merely passive for those massed listeners who might attend an Olympic stadium. A paper subsequently published in the Revue makes this clear. BourgaultDucoudray's La musique et le sport had been read originally at Coubertin's 1906 conference: it speaks of the "shock of the Beautiful" (la commotion du Beau) that a crowd is apt to feel, particularly when an aesthetic scene is presented to it in a "clear, simple, and grand form". ${ }^{17}$ Central to this shock is the role of large-scale choral music. For Bourgault-Ducoudray, this truly "popular art" is capable of expressing the aspirations and mentality of a people (people) long before they attain verbal definition and reward analytical enquiry. As such, he considers it a vital and immediate means of channelling the "new spirit" of the Olympic movement and fusing its accompanying socio-political message of unity with the "higher conception of the mission of art." ${ }^{18}$ The performance of choral music at sporting events, Bourgault-Ducoudray suggests, is an important step towards the realization of the Olympic dream - towards the "development", as he puts it, "of the idea that occupies us". ${ }^{19}$

Coubertin himself extended this position a few years later, when, in a five-part Revue article of 1911, he coined the term 'sporting Ruskinism (Ruskinianisme sportif)' as a means of capturing and conceptualizing the Olympic approach to aesthetics. ${ }^{20}$ The term itself, of course, pays specific homage to the work of the English aesthetician and art critic John Ruskin (1811-1900), chiefly because a crucial realization had allegedly woven its way through many of his writings. According to Coubertin, Ruskin - whom he dubs the "great English apostle of popular art" - had grasped the following:

The picture does not suffice: nor are the picture and the frame enough. It is also necessary that the spectator enters into the harmonic circle (le cercle harmonique) and its surrounding area, extending as far back as possible. Whether from the point of view of long experience or a developing artistic education, things (des choses) that are fairly beautiful or even beautiful in a mediocre sense - but are well associated with each other and with those who contemplate them - exert an influence far superior to that exercised by a very beautiful one that is poorly surrounded or poorly contemplated. ${ }^{21}$ Whether the spectator is aesthetically well-versed or in need of cultivation, then, he or she is written in to this artistic experience as the contemplator of many differently beautiful "things", into which category he or she is simultaneously placed as both 
experiencing subject and experienced object. Coubertin advances the term l'eurythmie to describe this situation: in so doing he deliberately adopts an ancient term (eurythmia) used by, for example, Vitruvius to indicate an attractive, coherent, and wellproportioned architectural façade, and a contemporary term (Eurhythmie) employed by Rudolf Steiner and others to signify a "visual speech" that expresses, through movement, mankind's innermost nature..$^{22}$

Coubertin's eurhythmy is thus a many-faceted concept: at times it defines a spontaneous "effect" or "gesture" that greatly intensifies individual beauties (we remember Bourgault-Ducoudray's "shock of beauty"); at times, with something of a socialist resonance derived from Ruskin, it describes a specific aptitude of the modern masses, who are "much more sensitive to the perfection of collections of things than to the separate details" (in Coubertin's words); at still other times, it is a "sense" or display of "taste" on the part of the artist that can be developed through attention to minute details. ${ }^{23}$ These latter are evidently highly important: addressing them directly and at great length, the remaining parts of Coubertin's article establish the most promising "eurhythmic conditions" for sporting occasions. He writes, amongst many other things, of the optimum disposition, material, and colour of flags and lights; the arrangement of garlands and flowers, the placing of trees and torches; the shapes of spectator stands, porticos, triumphal arches, and canopies; and the dress and gestures of those in processions. ${ }^{24}$

Most significantly for our purposes here, Coubertin's Ruskinism encompasses not only the visual but also the aural. He realizes that music and sound may cast a more farreaching and profound spell than impressive sights alone, and thus incorporates these categories into his fantastic Olympic surroundings. Indeed, he goes so far as to state that no sporting event should take place without the assistance of music, and, as with other art forms, sets out detailed strictures on its use. Bearing in mind the open-air settings of many sports, he allows that military bands or wind orchestras will be likely choices of ensemble, but insists - compare Bourgault-Ducoudray - that large choirs of mixed voices singing in rich harmony will be more effective still. ${ }^{25}$ In a further moment of Romantic indulgence, he imagines a fencing contest that, illuminated by the moon and by numerous bonfires, takes place inside a forest clearing and calls upon the musical services of "a dozen choristers"; for a large arena, he proposes that the sounds of a "hunting band" (fanfare de chasse) alternating with choral singing makes for the most "exquisite and sporting effect". ${ }^{26}$ Music should not, moreover, be deployed only as prelude and interlude for sporting contests, but should be heard simultaneously with them so as to aestheticize their gestures; it should not offer lively mimicry of the action, but should be grave, melancholy, and solemn so as to form a "harmonious contrast" with the athletic display. Something by Palestrina or Rameau, Coubertin proposes, could endow a gymnastics contest with a "character of grandeur" that even the "least refined" spectator could sense and appreciate..$^{27}$

More intriguing still, Coubertin suggests that music is most effective when its source is distanced from its audience and when its performers are hidden: distance and invisibility can add enticing charm to even the most "barbarous" of sounds and ensure the crowd's engagement with its surroundings..$^{28}$ Imagining what he specifies as a "modern Olympia" in 1910, he had again written in the Revue of the "large choral masses alternating with distant fanfares" that would form the basis of future "Olympic symphonies." He adds there that architects must be consulted in order to address the 
specific problems of stadium acoustics, and that one solution will be the erection of screens (écrans) - presumably to channel the music towards its audience, but also, he suggests, to hide its performers from view. ${ }^{29}$

At these mentions of hidden brass-heavy ensembles in perpetual accompaniment, we will immediately think - as, indeed, does Coubertin - of the orchestra at Wagner's Bayreuth. ${ }^{30}$ Even so, we must take care of making too direct a connection here, and again of depicting Coubertin only as the devoted Wagnerian originator of a sporting Gesamtkunstwerk. As Brian Kane has recently shown, many examples of concealedorchestra performance practices can be found across French and German musical culture from 1800 onwards; steeped in Romantic aesthetics, they hold in common the desire to shut out the mundane, thereby enhancing the listener's experience and assisting music in its reputed revelation of a transcendent sphere. ${ }^{31}$ It is this goal, rather than a simple and direct Wagnerian homage, that Coubertin seems to seek. Through massed choral music and brass fanfares, emanating around his Olympic stadia as if from nowhere, he intends to cast his spell. Enclosed within the "harmonic circle" that he posits in the quotation above, his audience members - regardless of their level of cultural refinement - will be struck by a sudden revelation of beauty stemming from the things around them, and of which they form both a visual and, crucially, an aural part: the voices of those assembled, celebrating the exploits of the athletes, will mingle with the planned musical performances to create the overall transcendent eurhythmic effect.

To this point, what we have considered are lavish musical theories as presented to a modest readership in the pages of the Revue Olympique in the early years of the twentieth century. ${ }^{32}$ As Brown points out, however, Coubertin and his Olympic colleagues are rewarding objects of study because, hand in hand with their developing theoretical claims, they also aspired to be cultural practitioners and producers. Their careers are marked, in other words, by repeated experiments in the effects that they sought - experiments that stand outside both the manifesto-frame of the Revue and the bounds of the early Olympic Games themselves, and yet point towards them in telling ways.

As early as the summer of 1894 , for example, Coubertin had worked to create an abundance of aesthetic entertainments that will remind us of the eurhythmic theory discussed in the above. The occasion was an inaugural congress in the "amphitheatre" of the Sorbonne, organised to discuss the possibility of reviving the ancient Olympics. As if figuring this project musically between the speeches and debates, Coubertin treated his delegates to a performance of the Hymn to Apollo - a melody and text recently unearthed at Delphi, transcribed by Théodore Reinach, and adapted for solo voice, choir, and small ensemble by Gabriel Fauré. ${ }^{33}$ Though he later described this performance as the grand coup in convincing his guests ("a subtle feeling of emotion spread through the auditorium as if the antique eurhythmy were coming to us from the distant past"), it is the subsequent evening entertainment that is of still greater interest in our terms. ${ }^{34}$ As part of a fête de nuit (night festival) in the grounds of the Paris Racing Club, Coubertin's guests witnessed an impressive array of events, apparently occurring simultaneously or in quick succession:

On a summer's night as serene as we could hope for, the lawn of the Croix Catelan was illuminated with sparkling brilliance. There were foot races, and clashes of arms by torchlight. M. Lejeune's fireworks brought proceedings to a close. Trumpet calls 
alternated with military bands concealed amidst the trees. The spectators were left in a state of great enthusiasm. ${ }^{35}$

We can certainly believe that they were: again, musical concealment married with artificial illumination and the thrill of the sporting body in order to captivate Coubertin's guests. Moreover, in the summer of 1906, it is evident that his delegates were enthralled once again. Within the frame of another consultative congress - in this case the one convened to discuss the role of the arts at the Olympics - Coubertin assembled another variety programme that combined speeches with recitations on ancient themes and performances of chansons by Costeley and Janequin, as well as Camille Saint-Saëns's two choral songs after Victor Hugo (Op. 53) and BourgaultDucoudray's chorus "Nos Pères". True to his favoured gestures of concealment, he also arranged for hunting horns to sound a rallying call from the nearby vestibule of the Sorbonne palace; this brought "echoes of the most charming effect", as he puts it, and served as the signal for a highly aestheticized fencing contest to begin, in which one competitor attacked "in an academic manner marvellously suited to the majesty of the building." Once again, Coubertin reports that all those present took with them a resounding "impression of eurhythmy." 36

It would not be difficult to find many additional instances of such festival experiments in aesthetic seduction. In 1914, for example, in celebration of twenty years of the Olympic movement, the Marquis de Polignac reimagined an ancient sporting festival at the Collège d'Athlètes at Reims, as part of which naked footraces took place to the accompaniment of Debussy's choral music from Le Martyre de Saint-Sebastien. ${ }^{37}$ Most virtuosically of all, under the auspices of a Parisian international architecture competition in May 1911, Coubertin and Pottecher put together another variety programme that took place in the courtyard in front of the Sorbonne chapel. Its description in the Revue is worth citing at length, in order to capture the dense weave of its many attractions and music's special role within:

At nine o'clock three shots gave the signal: in the great silence of the assembly suddenly attentive, almost without light, the scene deserted - we heard the wonderful prelude to Debussy's L'enfant prodigue. A moment later, the orchestra played the procession from the same work, and the great door of the church, turning on its hinges, gave passage to a hundred gymnasts, alternately carrying lighted torches and large green palm fronds. When these young people had filled the scene and created an immense arc on each side of the great steps, sixteen semi-naked Ephebes, a circle of gold in their hair, appeared four by four and executed a series of Hellenic exercises together: every sport - wrestling, throwing, discus, running - was recalled in turn. ... Then a little procession: wearing costumes of the time, players of hurdy-gurdies and bagpipes slowly circled the scene from which the gymnasts carrying torches and palms had just disappeared. And to complete this evocation of the athleticism of the Middle Ages, a soldier, holding the great sword upon his shoulder, appeared at the top of the steps. It was M. Viannene of the Comic Opera who sang, accompanied by the invisible orchestra, the "Pas d'armes du roi Jean" by Saint-Saëns. Again the stage was emptied, darkness spread throughout, and the orchestra played Berlioz's Trio for two flutes and harp..$^{38}$

Perhaps what is most striking here is not only that the musicians - mostly hidden behind "artificial foliage" - interject upon and accompany the sporting action, but that they mediate the flux of historical athleticism on display and channel it towards what, 
it later becomes clear, are the highpoints of the event: the concluding performance of Pottecher's specially written drama The Philosopher and the Athletes and the awarding of the Olympic medal for architecture..$^{39}$ Debussy's cantata L'enfant prodigue (The prodigal son) begins by suggesting ancient otherness through gentle woodwind arabesques, while the instrumentation of Berlioz's Trio, from his oratorio L'enfance du Christ ("The Childhood of Christ"), makes immediate aural gestures in a similar vein. Saint-Saëns's orchestral song, meanwhile, is a rousing setting of Victor Hugo's chivalric ballad, replete with musical faux-medievalisms.

Tracing the course of this path from ancient to modern and back again, those listening might be expected to hear the benediction of history for the present-day project of Olympism, just as, through the highly stylized transports of the concealed musicians, they could transcend the present and glimpse the Olympic ideal. Coubertin, for one, waxes lyrical on this account: "The audience moved away slowly," he writes, "taking with them a lasting and beneficial memory from this unforgettable festival. Until now ... and in spite of the almost inevitable imperfections of detail, something so perfectly eurhythmic has never been attempted and realized." ${ }^{40}$

\section{A "Festival of Vulgarity"}

Yet, as eurhythmic as all these combined entertainments may have been, it is no less evident that there exists a hard point of contradiction between these fêtes and contemporary Olympic theory as it was being simultaneously expounded in the Revue. In the periodical, it had been made clear repeatedly that the presence of the people was the sine qua non of the true eurhythmic experience. Writing in 1906, for instance, Bourgault-Ducoudray had given the striking example of a Breton drama attended both by local inhabitants and by practiced aesthetes invited from Paris. Tellingly, it was the former body - the inexperienced and "less jaded" public - who had been at the heart of the vibrant artistic experience:

Never have I seen such enthusiasm occur. The popular element and the literate element became united by a profound and sympathetic emotion. And in the evening, after the performance, [there was] the same close harmony between the Parisian luminaries and the people (peuple). Right next to the top table stood the table for the people's banquet - lively, noisy, full of jubilant Bretons. [There is] nothing so eloquent as this spirit, nothing so contagious as this exuberant joy, nothing so moving as the participation of diverse social classes in the same sentiment of enthusiasm, the same exaltation of art. ${ }^{41}$

Not so much resolving as sublimating, this joyous "exaltation of art" had apparently been driven from beneath by the exuberance of the local Bretons. Their presence, the author implies, had helped to generate the higher transcendent artistic experience by which all classes could be enthralled, and in which all classes could share. Thus, they resemble the "crowd" that Coubertin's writings had cited and that, as he had proposed, were particularly alive to the wonder of eurhythmic experiences.

31 Moreover, Brown furnishes the additional context of late nineteenth-century French cultural republicanism for grasping the intellectual foundations and popular aspirations of such ideas. Bringing together concerns for "strong ties between popular spectacles, public art, moral education, and social unity," this brand of republicanism might be most readily linked to Coubertin's close friend and collaborator Maurice 
Pottecher, and the largely amateur and community-based Théâtre du Peuple (people's theatre) that he ran at Bussang in the Vosges region. ${ }^{42}$ But we can feel its resonance, too, in the grand setting, intricate level of aesthetic planning, and marked preference for a primarily French musical tradition evident within Coubertin's fêtes. As only one example, another way of approaching the musical offerings of the grand Sorbonne palace fête of 1906 would be to note its drawing of a continuous line that extends from the French Renaissance chanson to Saint-Saëns's orchestral songs after Hugo. The second of these, the Chanson d'ancêtre, imagines the proud ancestors who "broke free from their chains" and vanquished those who would oppress them. "Frappez, écoliers/ Avec les épées/Sur les boucliers" is its refrain and its moral. ${ }^{43}$

But despite such resonances, no such body of "people" was in evidence at Coubertin's experimental fettes at the Sorbonne and elsewhere, and in this sense his eurhythmy could hardly become the quintessential "popular art" that he had envisaged and ultimately claimed to have derived from ancient culture. ${ }^{44}$ Instead, the events described in the last section were delivered to relatively small and select gatherings of the wealthy, influential, and powerful - those who, perhaps flattered by the impressive aesthetic programme before them, would dip their hands into deep pockets in order to provide the necessary funding for the project..$^{45}$ It is telling in this regard that the suspension of the predominantly French musical lineage on display in the Sorbonne event of 1906 comes as a result of the necessity of patronage. As part of the same conference programme, the royal hymn of Italy rang out as a means of honouring Count Tornielli, the Italian ambassador to Paris, and through him, securing the continuing support of the Duke of the Abruzzi and the Italian King. ${ }^{46}$

It might, of course, be argued that the absence of a people to engage this "popular art" was a contradiction foreseen by Coubertin and destined to be resolved once the Games were placed before the world audience. But in turn this very expectation lays bare a striking impasse at the heart of the Olympic aesthetic project. For, as soon as design and implementation were taken away from Coubertin and his native France - that is, handed over to National Organising Committees, scaled up, and made part of the Olympic Games themselves - it is evident that Coubertin's enthusiasm for and belief in eurhythmy very rapidly waned. In 1910, for example, four years after the Sorbonne conference held specifically to address the role of olympic arts (and its accompanying celebrations) we find him bemoaning various aesthetic aspects of the Games up to that point. Not the least among these is that, in London in 1908, music had been "utterly forgotten from beginning to end." Indeed, what was heard had been confined to "bursts of brass music" and "the old favourites of the town bands." Here his choice of words seems deliberately belittling, as if this "popular" music - the peals of lowly brass bands - had hardly conformed to the exalted musical offerings he had imagined and himself staged at the inaugural fêtes sportives. ${ }^{47}$

Part of the context here may well have the failure of the British Organising Committee to deliver on the planned Olympic Fine Arts medal competitions, a pet project of Coubertin's since at least $1906 .{ }^{48}$ Indeed, responding to Stockholm in 1912 - the eventual initiator of the arts competitions - Coubertin cut a far more positive figure, noting specifically that the Swedes had responded directly to the appeals of the 1906 artistic congress, and had been "meticulous" in the aesthetic design of their Games (including the deployment of "immense choral masses"). ${ }^{49} \mathrm{He}$ complains, however, that the "obligatory principle of simultaneity" founded at his congress had not been 
properly observed, and thus that the sporting body on display had not become appropriately aestheticized:

The several thousand singers, for example, had been grouped and exercised with an indefatigable zeal by the engineer Hultqvist, a man so devoted to the progress of choral singing. But they only appeared when the athletes were not there.... What an effect would have been produced by these thousands of human voices, saluting, for example, the conclusion of a great athletic attempt, or crowning in the Stadium a day of muscular effort, or welcoming the entrance of the royal procession or the proclamation of the victors! In place of this, great "concerts" were organized. But what was Olympic about these concerts, and why give them in a stadium emptied of its actors? This was a serious error. ${ }^{50}$

Ultimately, he continues, the foundational question must be whether the will is present to "create eurhythmy, to organise ensembles of beauty" at the Olympic Games. His answer for Stockholm in 1912, as London in 1908, seems to be that this will was found sorely wanting. With what must be read as a cutting allusion to Theodor Pinet's Olympiska Spelen - a "valse boston" composed especially for Stockholm - Coubertin concludes that "a waltz, a potpourri, variations on familiar themes" could never strike the appropriately solemn tone. Rather, "occasional orchestral music, frequent choral song, long silences, unexpected fanfares" are what is required; if "national and popular songs" are to be included, then they must be heard alongside, and thus elevated by, the presence of the "great classical works". This would be the best means of communicating the identity of the Olympiad and linking to its socio-cultural mission: its projection of "a public and majestic cult, dedicated every four years to life, to humanity, and to the eternal renewal of youth." ${ }_{51}$

As these responses suggest, Coubertin typically laid the blame for aesthetic failings at the door of the relevant National Organising Committee - the members of which, he suggests, had not yet grasped the solemn concept of eurhythmy, the importance of singular details, or the recommendations of the 1906 congress. "In this very new order of ideas," he reflects, "experience is lacking," and thus he seems optimistically to focus towards the renewed efforts of the future..$^{52}$ Yet in his opening address for that congress, he had also taken aim in a different direction, railing at those who would attend his Games, and denying them the very ability that, elsewhere, he had made their steadfast possession:

[W]e have lost all sense of eurhythmy. Today, the masses are incapable of linking the pleasures of various sorts of art together. They are used to scattering such pleasures into bits, lining them up in rows, and pigeonholing them. They do not find the ugliness and vulgarity of their surroundings offensive. Beautiful music stirs them, but it is a matter of indifference to them whether or not that music resonates within a noble architectural setting. Nothing in them seems to revolt at the miserably mundane decor, the ridiculous processions, the detestable cacophony, and the whole apparatus attendant upon what is called a "public festival" these days. One guest is always missing at these festivals: good taste. ${ }^{53}$

We might reflect that, in the final phrase, Coubertin's overall position is most clearly revealed. He writes summarily of "good taste": however meticulously an obedient organising committee might prepare, still this might be lacking, a far cry from the successes of his fêtes sportives. And far more seriously than that, good taste might not be native to the Olympic masses, who, whatever was placed before them, would remain 
unable to discern and unable to synthesize towards an all-embracing eurhythmy. Thus, the existence and value of that in which they took part would endure as a mystery to them; they would continue to revel in the base vulgarity - the peals of the brass bands and the sways of the popular waltzes - to which they had become accustomed amidst the fragments of modern culture.

This, then, is the flip side of Coubertin's Olympic aesthetics. Constrained by the background of "good taste" from which his aesthetic ideas had emerged, and frustrated that his time had not yet come - and perhaps, in spite of all his efforts, never would he is equally capable of radiating disappointment and disaffection as promises of universal humanity. For all the apparent success of his early Games in the first decades of the twentieth century, still he strikes the pose of the grumbling, alienated, superior modernist.

\section{A Festival of "Olympic Youth"}

It may come as a surprise, then, to read the following, part of Coubertin's closing speech from the Summer Games of 1936. These took place the year before he died; the speech was delivered in his absence due to ill health:

Soon the Games of 1936 will be no more than a memory, but what powerful and diverse Games they were! Those memories will be of beauty, first and foremost. Since the time I called the Conference on Arts, Literature, and Sports thirty years ago in Paris to establish a permanent connection between the restored Olympics and expressions of the mind, bold efforts from Stockholm to Los Angeles have helped make this ideal a reality. Now, Berlin has made this link a permanent feature of the Games, through such gallant and utterly successful initiatives as the Race of the Sacred Torch from Olympia, and the magnificent Festival held in the monumental Stadium on the opening night of the Games. Both events were instituted by my genial and enthusiastic friend, Carl Diem. 54

These words sound very much like an expression of culmination, the satisfied end of a life spent in the pursuit of beauty. In particular, the mention of the 1906 Paris conference, presumably obscure to many of Coubertin's listeners, serves only to augment this personal resonance. After thirty years of striving, Coubertin seems to want to tell us, finally the moment had arrived for "expressions of the mind" to become permanently and properly integrated into the Olympic festival.

The 1936 Summer Games in question are notorious, and perhaps the most studied of all Olympic festivals. They were the first Games to take place in Germany; postponed from 1916 due to war, they were steered back towards Berlin under the careful stewardship of Theodor Lewald from the late 1920s until the IOC's point of decision in May 1931. Though initially rejected by the National Socialists as antithetical to their völkisch ideology, they were soon seized upon by Hitler and the party's high command as a large-scale propaganda opportunity. In our present discourse, they are therefore usually glossed as the "Nazi" Games, and typically seen as a grand feat of "theft" or deception, a cynical appropriation of Olympic trappings in order to project - both inwards and outwards - the image of a strong, thriving, and peaceful nation united behind its leader. ${ }^{55}$ 
Certainly, we could read the Berlin Games' aesthetic components in this way: as a careful pandering to Olympic strictures that simultaneously serves as an expression of their seamless interlock with German cultural heritage and national will. The famous and grandiose opening ceremony, for example, brought together ritual elements of Olympism already established - the lighting of the flame, the hoisting of flags, the procession of athletes, the mass release of doves - with performances of Handel's "Hallelujah" Chorus and of Richard Strauss's Olympische Hymne ('Olympic Hymn'). ${ }^{56}$ As Albrecht Dümling points out, this latter work combines allusions to both the Deutschlandlied and to Beethoven's Ninth Symphony; we might well believe that, knowing of its creation especially for the Games, Coubertin was duped into trusting its apparent message of openness and brotherhood. ${ }^{57}$ Indeed, later in his Games closing speech Coubertin cited not only Schiller's "Ode to Joy" but one of Hitler's expansionist slogans: "Wir wollen bauen!" ("We wish to build!"), he proclaims, and thus momentarily twins the consolidation of Olympism with that of the Nazi state. ${ }^{58}$

But this view of the "duped" Coubertin is greatly complicated by his close involvement throughout the planning process for 1936. As we have seen, his closing speech singles out the General Secretary of the German Organising Committee, Carl Diem, for particular praise, and thus celebrates a personal connection that had been made more than twenty years before. Diem had originally been appointed to design the Berlin Games of 1916; thus from at least 1913 onwards, he and Coubertin had enjoyed a friendship based on a common love of opera, theatre, and archaeology, and the drive to create a working template for future Games, not least in their aesthetic aspects..$^{59}$ Accordingly, it is hardly surprising to find that Diem's memoirs stress Coubertin's desire to keep an overview of the 'harmonic consonance of word, deed, and music' for 1936, and that it was Coubertin ("a musical man") who had proposed individual musical items for their celebration: Handel's 'Hallelujah' for the opening ceremony, for example. ${ }^{60}$

4 A more convincing interpretation of Coubertin's position, accordingly, is that the Summer Games of 1936 represented his last hurrah, as mediated by Diem. It was then, as Elizabeth Schlüssel puts it, that he saw "his ideas and tastes realized in full for the first time." ${ }^{61}$ A lifelong cultural Germanophile, Coubertin had waited over twenty years for a German Olympics; on the back of the eurhythmic failings of the Games up to that point, he took advantage of his friendship with Diem, we might say, in order to influence the aesthetic aspects of what would be presented to the crowds in Berlin. Diem described Coubertin at this time as a 'dictator in velvet gloves', someone who knew very clearly what he wanted and how to convince others of it gently and efficiently. So, it was that Diem was made to give specific assurances that the German Games would be as aesthetically rewarding as Coubertin's early Parisian fêtes had been. 62

Even more so than in the case of the lavish opening ceremony, these claims are borne out by Olympische Jugend ('Olympic Youth') - the Festspiel ("festival play", a term with strong Wagnerian connotations) performed in the Olympic stadium on the opening night and praised, as we have seen, by Coubertin in his concluding remarks. Written by Diem, this was a pageant comprising a series of loosely connected scenes, each showcasing the formation dancing of many thousands of children and young people and mostly scored for orchestra by Werner Egk and Carl Orff. The second part, for example, proceeded as follows, to the accompaniment of music by Orff: 
Second scene: The Maidens' Grace. As the children exit by the Marathon Gate, the searchlights pick out 2300 girls, 14 to 18 years old, who stream in from the East Steps and dance a round on the grass. From their midst a single figure emerges and dances a waltz. Then exercises with balls, hoops, and clubs; the scene ends in a round dance for all. ${ }^{63}$

In the fourth scene, two warriors staged a fight to the death, whereupon young women danced a dirge for the fallen. The whole ended with the beams of massive searchlights fired into the sky, forming a "dome of light" above the arena and joining the waving flags and flaming beacons at its upper edge.

Olympische Jugend was, in short, a lambent display of German might. The official report leaves no doubt as to its meticulous organisation and the many thousands of people involved in its production. ${ }^{64}$ But by the same token, we might also understand this Festspiel as a realization of Coubertin's long-held wishes: as a eurhythmic fête de nuit brought to the largest stage, eventually seen by as many as half a million people, and quite unlike anything seen at the Games to this point. ${ }^{65}$ This identity is evident from the surface elements, many of which will remind us of Coubertin's French fêtes of earlier in the century - the stylized battle, the sporting exercises, the use of light and flame, Egk's hymn to Olympia (in the third scene), and Orff's deliberately "ancient" instrumentation and folksong motivic language. ${ }^{66}$

But it is also clear from the "eurhythmic" aesthetics that underlie and unite these elements. From his earliest sketches onwards, Diem conceived of "a great festival play in the stadium, in which all the magical powers of music, song, dance, and light work together." This was not to be theatre in the conventional sense: not, in Diem's words, a "self-contained intellectual event placed before the spectator, and with which he must reckon." Rather, it was something of which the audience was itself a part, "the young people in the centre, surrounded and borne along by a festival community (Festgemeinde)." In Olympische Jugend, according to Diem's slogan, 'youth should present itself to itself ${ }^{67}$

Such integration was attempted, of course, through Coubertin's established visual and choreographic means: the all-enclosing stadium, the ebb and flow of dancers from all areas of the visual field, the use of light and darkness. But it drew, too, from his earlier musical recommendations. As the official report shows, recording, relay, and loudspeaker technologies were employed throughout the piece in order to minimize the presence of the orchestral performers, and to maximize the resonant embrace of bells: a recording of the well-known Glockenspiel of the Potsdam Garnisonkirche was played during the dancers' Olympic flag formation at the end of the third scene. ${ }^{68}$ Above all, as Egk confirms, the musical trajectory culminated in the grand finale under the dome of light and fire, in which all performers entered the arena for a performance of what is identified as the "Olympic Hymn" - in this case the 'Ode to Joy' from the end of Beethoven's Ninth Symphony. ${ }^{69}$ Countless sources confirm that such an apotheosis had been Coubertin's utmost wish for decades, and that he had specifically demanded it to crown a German Games. ${ }^{70}$ Small wonder, then, that Diem stresses Coubertin's close interest in the development of the pageant, and, at its premiere, records the arrival of a telegram "brimming with thanks" from Lausanne, where the aged Coubertin had followed the whole performance on Genevan radio. ${ }^{71}$ 


\section{Conclusion: An 'Unfinished Symphony'}

50 We might conclude by stating, then, that Coubertin at last got his aesthetic wish. Through Carl Diem's Olympische Jugend, the experimental and "eurhythmic" fêtes de nuit of the century's early years were finally raised to the level of an Olympic Games, crowned by a performance of Beethoven's "Ode to Joy," and experienced by hundreds of thousands of people. Yet, of course, this is a necessarily uneasy conclusion. As we have seen, Olympic and Fascist strands had become tightly intertwined here: in 1936, Coubertin's 'crowd' was readily represented as the German Volksgemeinschaft ('people's community'), a body politic overawed and seduced by sublime aesthetic means and focused back towards the allegedly ancient roots of its contemporary strength. By the same token, Olympism's sporting exercises for international peace were all too easily redirected towards another goal, namely the ever-intensifying mobilization - 'Wir wollen bauen!' - of the German national body for the waging of expansionist war. From this point of view, the Potsdam bells at the end of the pageant's third scene were far more than a benign symbol of Prussian heritage: since these had also featured prominently as part of the soundscape of Hitler's propagandistic 'Day of Potsdam' after his election in 1933, they also inevitably rang for the dawn of his 'new order', spearheaded by the thousands of young people now performing in the Berlin arena. ${ }^{72}$

51 As one commentator has put it, we might therefore see Coubertin at the end of his life as the 'prisoner of his own utopia' - enthralled by his own aesthetic idea of eurhythmy, and entrapped by the dogged belief that its marriage with sporting display must be for the betterment of humanity and its pursuit of international peace. ${ }^{73}$ Indeed, when some in the contemporary French press - well aware of the danger of national interests outweighing international ones - questioned the political astuteness of the Olympic movement, Coubertin's response is telling in its lack of compromise and its insistence that sport must stand above and subsume political tensions:

André Lang [interviewing Coubertin in Le Journal, August 1936]: Don't you find the selection of Tokyo and the desire of the Japanese to astound the world in 1940 fraught with rather dangerous consequences?

Coubertin: Not at all. I am glad of it. I wanted it. I consider the arrival of the Games in Asia a great victory. In terms of Olympism, the only thing international rivalries can be is fruitful. It is good for every country in the world to have the honor of hosting the Games and to celebrate them in their own way, according to the imagination and means of its people. In France, people are worried that the 1936 Games showcased Hitler's strength and discipline. How could it have been otherwise? On the contrary, it is greatly to be desired that the Games should gladly wear the clothing that each country weaves during the four years of preparation for them.... The example of Germany is there to show us what can be achieved if you make it your business to focus on working. ${ }^{74}$

52 Yet, as obdurate as he may have been in the face of such press questioning, we should also finally accept that the elderly Coubertin displayed, in other venues more intimate, a more reflective side. On the eve of the 1936 Games, he had written a brief document apparently intended as the beginning of the last volume of his memoirs. In this - titled, in a final musical metaphor, 'The Unfinished Symphony' ('La symphonie inachevée') he likens himself to a composer, one who had not only written a magnum opus but had enjoyed the privilege of hearing it performed and seeing it endure. Olympism, he 
suggests, had been this work, occupying a lifespan bookended on the one hand by 'Napoleon III and the 1867 Universal Exhibition in Paris' and on the other, the 'strange' - this his only adjective - phenomenon of Adolf Hitler. Even so, he continues, Olympism was one 'loud and insistent' movement only; it must now be followed by 'slow, silent, gradual, and long thought-out study' dedicated to 'the principle of a completely new type of education'. ${ }^{75}$

Perhaps we should at last read this as valedictorian - as Coubertin's late realization that his dream of grand, serious, and eurhythmic festivals, born of late nineteenthcentury French pomp, its republican inheritance, and a personal taste for the exalted German musical canon, could make little room for their message alongside the spectacles of twentieth-century political styles. Perhaps it is an admission, too, that an aesthetic withdrawal or transformation had therefore become necessary. If so, it might be added that certain postwar Olympics followed just this path: as Elizabeth Schlüssel has shown in great detail, the 1972 Summer Olympics in Munich - the first in Germany since 1936 - were reimagined as 'heitere Spiele' ('carefree Games'), for which Kurt Edelhagen's big band provided some of the opening soundtrack. ${ }^{76}$ This would hardly have met Coubertin's expectations of solemnity, or gravity, or the nobility of the ancient world; nor, one strongly suspects, would it have been at all to his musical taste. But perhaps, at the very least, he would have accepted its necessity, his eurhythmic festival dream having reached its limits with so much else in the first half of the new century.

Barker, Philip. “The Anthem: Olympism's Oldest Symbol." Journal of Olympic History 12/2 (2004): 46-53.

Brown, Douglas. "Modern Sport, Modernism and the Cultural Manifesto: De Coubertin's Revue Olympique." The International Journal of the History of Sport 18/2 (2001): 78-109.

Brown, Douglas A. "Pierre de Coubertin's Olympic Exploration of Modernism, 1894-1914: Aesthetics, Ideology and the Spectacle." Research Quarterly for Exercise and Sport 67/2 (1996): 121-35.

Brown, Douglas A. "Revisiting the Discourses of art, beauty and sport from the 1906 Consultative Conference for the Arts, Literature and Sport." Olympika: The International Journal of Olympic Studies 5 (1996): 1-24.

Coubertin, Pierre, de. Coubertin autographe. Edited by Jean Durry. Yens-sur-Morges : Cabédita, 2003.

Coubertin, Pierre de. Les batailles de l'éducation physique. Une campagne de vingt-et-un ans, 1887-1908. Paris : Librarie de l'Éducation Physique, 1908.

Coubertin, Pierre de. Mémoires de jeunesse. Edited by Patrick Clastres. Paris : Nouveau Monde, 2008.

Coubertin, Pierre de. Olympic Memoirs. No translator given. Lausanne: International Olympic Committee, 1997.

Coubertin, Pierre de. Olympism: Selected Writings. Edited by Norbert Müller. Translated by William H. Skinner. Lausanne: International Olympic Committee, 2000.

Coubertin, Pierre de, ed. Revue Olympique, articles in various issues (1901-1914).

Diem, Carl. Ein Leben für den Sport. Erinnerungen aus dem Nachlass. Ratingen: Henn, 1974.

Diem, Carl. Gedanken zur Sportgeschichte. Schorndorf: Hofmann, 1965. 
Diem, Carl. Olympische Flamme. Das Buch vom Sport, 1. Berlin: Deutscher Archiv, 1942.

Diem, Carl. Olympische Jugend. Festspiel zur Aufführung im Olympia-Stadion am Eröffnungstage der XI. Olympischen Spiele in Berlin. Berlin: Reichssportverlag, 1936.

Dümling, Albrecht. "Von Weltoffenheit zur Idee der NS-Volksgemeinschaft. Werner Egk, Carl Orff und das Festspiel Olympische Jugend.” In Werner Egk: Eine Debatte zwischen Ästhetik und Politik, edited by Jürgen Schläder, 5-32. Munich: Herbert Utz, 2008.

Dümling, Albrecht. "Zwischen Autonomie und Fremdbestimmung. Die Olympische Hymne von Robert Lubahn und Richard Strauss.” Richard Strauss-Blätter 38 (1997): 68-102.

Fritzsche, Peter. Life and Death in the Third Reich. Cambridge, MA: Harvard University Press, 2008. Guegold, William K. 100 Years of Olympic Music: Music and Musicians of the Modern Olympic Games, 1896-1996. Mantua, OH: Golden Clef, 1996.

Hon, Giora and Bernard R. Goldstein. From Summetria to Symmetry: The Making of a Revolutionary Scientific Concept. New York: Springer, 2008.

Hugo, Victor. Oeuvres complètes, vol. 13. Paris: Hetzel-Quantin, 1893.

Kane, Brian. Sound Unseen: Acousmatic Sound in Theory and Practice. New York and Oxford: Oxford University Press, 2014.

Kent, Graeme. Olympic Follies: The Madness and Mayhem of the 1908 London Games. London: JR Books, 2008.

Large, David Clay. Nazi Games: The Olympics of 1936. New York: W. W. Norton, 2007.

Lyberg, Wolf. “Sweden: Stockholm 1912-1956.” Olympic Message 2 ['The Olympic Games and Music']: 44-7.

MacAloon, John J. "Olympic Games and the Theory of Spectacle in Modern Societies." In Rite, Drama, Festival, Spectacle: Rehearsals Toward a Theory of Cultural Performance, edited by John J. MacAloon, 241-280. Philadelphia: Institute for the Study of Human Issues, 1984.

Mallon, Bill and Ture Widlund. The 1896 Olympic Games: Results for All Competitors in All Events, with Commentary. Jefferson, NC: McFarland, 1998.

No editor given. XI Olympiade Berlin 1936. Amtlicher Bericht. Berlin: Organisationskomitee für die 11. Olympiade, 1937.

No editor given. Anweisungen für die Eröffnungsfeier der 11. Olympiade, Berlin 1936. Berlin: Organisationskomitee für die 11. Olympiade, 1936.

Schlüssel, Elizabeth. Zur Rolle der Musik bei den Eröffnungs- und Schlußfeiern der Olympischen Spiele von 1896 bis 1972. Doktorarbeit; Deutsche Sporthochschule Köln: Cologne, 2001.

Segrave, Jeffrey O. “'All Men Will Become Brothers' ('Alle Menschen werden Brüder'): Ludwig van Beethoven's Ninth Symphony and Olympic ideology." In Sport, Music, Identities, edited by Anthony Bateman, 38-52. Abingdon: Routledge, 2015.

Sheppard, Jennifer R. "Sound of Body: Music, Sports and Health in Victorian Britain." Journal of the Royal Musical Association 140/2 (2015): 343-369.

Stanton, Richard. The Forgotten Olympic Art Competitions: The Story of the Olympic Art Competitions of the 20th Century. Victoria: Trafford, 2000.

Toncheva, Svetoslava. Out of the New Spirituality of the Twentieth Century: The Dawn of Anthroposophy, the White Brotherhood, and the Unified Teaching. Berlin: Frank \& Timme, 2015. 
Walters, Guy. Berlin Games: How Hitler Stole the Olympic Dream. London: John Murray, 2006.

\section{ENDNOTES}

1. See Douglas A. Brown, "Pierre de Coubertin's Olympic Exploration of Modernism, 1894-1914: Aesthetics, Ideology and the Spectacle," in Research Quarterly for Exercise and Sport 67/2 (1996): 121-35.

2. Quoted from Coubertin's essay "L'Art et le Sport" in Brown, "Pierre de Coubertin's Olympic Exploration of Modernism," 127. Brown's translation.

3. This summary and the one in the previous paragraph drawn from Brown, "Pierre de Coubertin's Olympic Exploration of Modernism," 123-4.

4. Brown, "Pierre de Coubertin's Olympic Exploration of Modernism," 129-31.

5. See William K. Guegold, 100 Years of Olympic Music: Music and Musicians of the Modern Olympic Games, 1896-1996 (Mantua, OH: Golden Clef, 1996). Also Olympic Message 2 ['The Olympic Games and Music'] (April-May-June 1996; publ. International Olympic Committee, Château de Vidy, Lausanne).

6. See Philip Barker, 'The Anthem: Olympism's Oldest Symbol', Journal of Olympic History 12/2 (2004): 46-53 and Richard Stanton, The Forgotten Olympic Art Competitions: The Story of the Olympic Art Competitions of the 20th Century (Victoria: Trafford, 2000).

7. See Elizabeth Schlüssel, Zur Rolle der Musik bei den Eröffnungs- und Schlußfeiern der Olympischen Spiele von 1896 bis 1972 (Doktorarbeit; Deutsche Sporthochschule Köln: Cologne, 2001). 'Eurhythmie' is mentioned on p. 85. My thanks to the author for assisting me in obtaining a copy of her thesis.

8. Jeffrey O. Segrave, “'All Men Will Become Brothers' (“Alle Menschen werden Brüder”): Ludwig van Beethoven's Ninth Symphony and Olympic ideology," in Sport, Music, Identities, ed. Anthony Bateman (Abingdon: Routledge, 2015), 38-52, quotation at 41.

9. See Pierre de Coubertin, Mémoires de jeunesse, ed. Patrick Clastres (Paris: Nouveau Monde, 2008), 25, 46, and 63 (quote). 'Agram' was the contemporary Austro-German name for Zagreb; Coubertin explains (61) that he chose it for his imagined state since he liked its euphonious sound and actually knew very little of its associated history and geography. All translations from French and German are my own unless otherwise noted.

10. For an example of a Wagner trip, see the letter of October 1902 in Pierre de Coubertin, Coubertin autographe, ed. Jean Durry, 137, in which Coubertin mentions a recent trip to Bayreuth to hear the Ring, Parsifal, and Der fliegende Holländer. On his view of Beethoven's Ninth ('the harmony of the piece seemed to communicate with the Divine'), see the 1935 essay "The Philosophic Foundation of Modern Olympism" in Coubertin, Olympism: Selected Writings, ed. Norbert Müller, tr. William H. Skinner (Lausanne: International Olympic Committee, 2000), 583; on Gluck, see the 1927 essay “The New Panathenean Games” in Olympism, 279-80.

11. Coubertin, Olympic Memoirs, no translator given (Lausanne: International Olympic Committee, 1997), 76.

12. Norbert Müller, “Coubertin's Olympism' in Coubertin,” Olympism: Selected Writings, 43.

13. See Douglas Brown, 'Modern Sport, Modernism and the Cultural Manifesto: De Coubertin's Revue Olympique', in The International Journal of the History of Sport 18/2 (2001): 78-109, quote at 79. 
14. No author given, "Les décisions prises," Revue Olympique 6 (June 1906), 87-93 at 91. Where no specific author is identified for an article in the Revue Olympique, Brown makes the reasonable assumption that Coubertin himself wrote it: see, for example, Brown, "Pierre de Coubertin's Olympic Exploration of Modernism," 134n57, and for Coubertin's editorial practices, "Modern Sport, Modernism and the Cultural Manifesto," 86-90. I have made the same assumption about authorship throughout the present article.

15. On contemporary theories of the connection between singing and health, see Jennifer R. Sheppard, "Sound of Body: Music, Sports and Health in Victorian Britain," Journal of the Royal Musical Association 140/2 (2015): esp. 353-69.

16. "Les décisions prises," 91.

17. Louis Bourgault-Ducoudray, "La musique et le sport," Revue Olympique 7 (July 1906): 104-7 at 105.

18. Bourgault-Ducoudray, "La musique et le sport," 106.

19. Bourgault-Ducoudray, "La musique et le sport," 106.

20. Coubertin, "Décoration, Pyrotechnie, Harmonies, Cortèges. Essai de Ruskinianisme sportif," Revue Olympique 64 (April 1911): 54-9; 65 (May 1911): 71-6; 67 (July 1911): 106-10; 68 (August 1911): 122-4; 70 (October 1911): 149-53.

21. Coubertin, "Essai de Ruskinianisme sportif," Revue Olympique 64: 54.

22. On Vitruvius, see Giora Hon and Bernard R. Goldstein, From Summetria to Symmetry: The Making of a Revolutionary Scientific Concept (New York: Springer, 2008), 100-1; for an account of Steiner's eurhythmy, see Svetoslava Toncheva, Out of the New Spirituality of the Twentieth Century: The Dawn of Anthroposophy, the White Brotherhood, and the Unified Teaching (Berlin: Frank \& Timme), 154-63.

23. These descriptions can be found in Coubertin, "Essai de Ruskinianisme sportif," Revue Olympique 70: 150 and 64: 54-5.

24. 'Eurhythmic conditions' is found in Coubertin, "Essai de Ruskinianisme sportif," Revue Olympique 67: 109.

25. Coubertin, "Essai de Ruskinianisme sportif," Revue Olympique 68: 122-3.

26. Coubertin, "Essai de Ruskinianisme sportif," Revue Olympique 67: 108 and 68: 123.

27. Coubertin, "Essai de Ruskinianisme sportif," Revue Olympique 68: 122-3.

28. Coubertin, "Essai de Ruskinianisme sportif," Revue Olympique 68: 122-3.

29. Coubertin, "Une Olympie moderne," Revue Olympique 51 (March 1910): 42-3.

30. "It should not be forgotten that the invisibility of the performers was part of the innovating dogma of the Wagnerian aesthetic - a dogma that commands an increasingly convinced community of the faithful": Coubertin, "Une Olympie moderne," 43.

31. Brian Kane, Sound Unseen: Acousmatic Sound in Theory and Practice (New York and Oxford: Oxford University Press, 2014), esp. 99-113.

32. On the Revue's limited print run and readership, see Brown, 'Modern Sport, Modernism and the Cultural Manifesto', 86-90.

33. See the account given in Coubertin, Les batailles de l'éducation physique. Une campagne de vingtet-un ans, 1887-1908 (Paris: Librarie de l'Éducation Physique, 1908), 96.

34. This quotation from Coubertin, Olympic Memoirs, 21-2.

35. Coubertin, Une campagne de vingt-et-un ans, 96.

36. See [Coubertin], "La festival de la Sorbonne," Revue Olympique 6 (June 1906): 93-6. See also the account of the fencing contest in Coubertin, Une campagne de vingt-et-un ans, 200: “... a combat of classical allure, while hunting fanfares resounded from the vestibule of the palace. The eurhythmy of this festival - the first ever to combine sport, science, literature, and art - left those present with an unforgettable impression".

37. On Polignac's event at Reims, see the general account given under the title "Les fêtes olympiques de Reims," Revue Olympique 103 (July 1914): 110-11, and the press report in Brown, 
"Pierre de Coubertin's Olympic Exploration of Modernism," 129. Though the particular chorus by Debussy is not specified, one can imagine that Le Martyre's Act III Paean to Apollo and its preceding fanfares might have fitted the bill.

38. [Coubertin], "La fête olympique de la Sorbonne," Revue Olympique 66 (June 1911): 83-5 at 84.

39. This prize was given to the Swiss architect Eugène Monod; its awarding followed immediately on the performance of two Rameau choruses "while the old façade of the building was lit up by Bengal fire." See [Coubertin], "La fête olympique de la Sorbonne," 85.

40. [Coubertin], "La fête olympique de la Sorbonne," 85. See also the similar account in Coubertin, Olympic Memoirs, 129.

41. Bourgault-Ducoudray, "La musique et le sport," 105.

42. See Brown, "Pierre de Coubertin's Olympic Exploration of Modernism," 129-131. As Brown shows, Pottecher added sporting events and regional choral music to the programme of his Théatre du Peuple in August 1906: on this event, see the brief editorial account at the beginning of Pottecher, 'L'art dramatique et le sport', Revue Olympique 8 (1906): 117 and Coubertin, Une campagne de vingt-et-un ans, 200.

43. See Victor Hugo, Oeuvres complètes, 13 (Paris: Hetzel-Quantin, 1893), 261-4. To this point about French cultural republicanism, we might add the interjection of the anonymous editor certainly Coubertin himself - to Bourgault-Ducoudray's 1906 "La musique et le sport" article in the Revue Olympique. In an interval between the races at the Grand Prix of the Paris Racing Club in July 1906, Henri Radiguer had apparently led 160 singers and instrumentalists in a grand performance of five revolutionary-era French cantatas; this had been an "object lesson," as the editor puts it, in the validity of Bourgault-Ducoudray's claims about choral music and the expression of a people's essence. See Bourgault-Ducoudray, "La musique et le sport," 104.

44. For Coubertin's view of eurhythmy as the ancients' "popular art," see Olympic Memoirs, 129.

45. The typical figure cited for attendance at the Sorbonne conferences is 2000 people, the capacity of the venue's amphitheatre: see, for example, Brown, "Pierre de Coubertin's Olympic Exploration of Modernism," 127, and Bill Mallon and Ture Widlund, The 1896 Olympic Games: Results for All Competitors in All Events, with Commentary (Jefferson, NC: McFarland, 1998), 5.

46. Coubertin, "La festival de la Sorbonne," 95.

47. Coubertin, "Une Olympie moderne," 42.

48. On the ultimately unrealized plans for these competitions in London, see Graeme Kent, Olympic Follies: The Madness and Mayhem of the 1908 London Games (London: JR Books, 2008), 50-2.

49. Coubertin, "L'Art à l'Olympiade," Revue Olympique 82 (October 1912): 154-5.

50. Coubertin, "L'Art à l'Olympiade," 155.

51. Coubertin, "L'Art à l'Olympiade," 155 . The specific reference to a waltz is surely aimed at the Swedish organising committee: one of the musical centrepieces of the Games had been a "Valse Boston" composed by Theodor Pinet. See Wolf Lyberg, "Sweden: Stockholm 1912-1956," in Olympic Message 2 ["The Olympic Games and Music"], 44-7.

52. Coubertin, "L'Art à l'Olympiade," 155.

53. This speech reprinted in Coubertin, Olympism: Selected Writings, 611-12, quotation at 612.

54. This speech is reproduced in Coubertin, Olympism: Selected Writings, 519-20.

55. I use the word "theft" as an allusion to the subtitle of Guy Walters's book Berlin Games: How Hitler Stole the Olympic Dream (London: John Murray, 2006), a recent example of the ongoing popular fascination with these particular Summer Games. In his Nazi Games: The Olympics of 1936 (New York: W. W. Norton, 2007), David Clay Large writes of the "Nazi appropriation of the ancient Olympic heritage in 1936" and draws attention to the Games as both a "coming-out party on the world stage" and as an attempt to "win the hearts and minds of the German people." See 9-12; the information about the Games in my paragraph in the main text is drawn from 32-9, 49-52, and 63-65. 
56. For these details, I draw largely on the official report of the organizing committee: see XI Olympiade Berlin 1936. Amtlicher Bericht (Berlin: Organisationskomitee für die 11. Olympiade, 1937), esp. 544-7. See also Anweisungen für die Eröffnungsfeier der 11. Olympiade, Berlin 1936 (Berlin: Organisationskomitee für die 11. Olympiade, 1936), and for a musical summary of the ceremony, Schlüssel, 248-308.

57. See Albrecht Dümling, "Zwischen Autonomie und Fremdbestimmung. Die Olympische Hymne von Robert Lubahn und Richard Strauss," Richard Strauss-Blätter 38 (1997): 68-102.

58. Coubertin, "Message at the Close of the Berlin Games," in Olympism: Selected Writings, 520.

59. On this relationship, see Schlüssel, 250-9.

60. Carl Diem, Ein Leben für den Sport. Erinnerungen aus dem Nachlass (Ratingen: Henn, 1974), 161; also Diem, Gedanken zur Sportgeschichte (Schorndorf: Hofmann, 1965), 21.

61. Schlüssel, 250.

62. Diem, Ein Leben für den Sport, 88.

63. XI Olympiade Berlin 1936. Amtlicher Bericht, 577. The summary presented elsewhere in this paragraph is drawn from the same source, 577-84.

64. XI Olympiade Berlin 1936. Amtlicher Bericht, 584-7,

65. According to XI Olympiade Berlin 1936. Amtlicher Bericht, 587, the total number of spectators was 328093 - a figure made possible by repeat performances of the pageant over the next few weeks. The English version of the same report (The XIth Olympic Games, Berlin 1936. Official Report, 587) records "half a million persons altogether" as the total audience.

66. On Egk's and Orff's contributions, see their essays 'Musik zum Olympischen Festspiel' and 'Jugend musiziert für die Jugend' in the programme booklet Olympische Jugend. Festspiel zur Aufführung im Olympia-Stadion am Eröffnungstage der XI. Olympischen Spiele in Berlin (Berlin: Reichssportverlag, 1936), 33-8. Orff's essay makes clear his use of viols and recorders, as well as the simple 'folksong-like' melodic airs he adopted.

67. Carl Diem, Olympische Flamme. Das Buch vom Sport, 1 (Berlin: Deutscher Archiv, 1942), 279-81. See also the similar account in XI Olympiade Berlin 1936. Amtlicher Bericht, 577, and the director Hanns Niedecken-Gebhard's remarks in Olympische Jugend. Festspiel zur Aufführung im OlympiaStadion am Eröffnungstage der XI. Olympischen Spiele in Berlin, 31: "From the 'bird's eye' perspective, the spectators can see everything that happens ... every observer, wherever he sits, is given the total impression."

68. See XI Olympiade Berlin 1936. Amtlicher Bericht, 584-7 and Orff, "Jugend musiziert für die Jugend," 38.

69. See "Schlussbild: Olympischer Hymnus" in Olympische Jugend. Festspiel zur Aufführung im Olympia-Stadion am Eröffnungstage der XI. Olympischen Spiele in Berlin, 12-13.

70. For example, Diem, Olympische Flamme, 279-80; see also the evidence cited by Schlüssel, 250-9 and 335-44.

71. Diem, Ein Leben für den Sport, 161-2.

72. On the 'Day of Potsdam', see Peter Fritzsche, Life and Death in the Third Reich (Cambridge, MA: Harvard University Press, 2008), 44-5.

73. The quotation is the description of Yves Pierre Boulongne, as cited in Coubertin, Olympism: Selected Writings, 519.

74. See Lang, "The Games in Tokyo in 1940?" in Coubertin, Olympism: Selected Writings, 520-2 at 521.

75. Coubertin, “The Unfinished Symphony," in Coubertin, Olympism: Selected Writings, 751-3.

76. See the discussion in Schlüssel, 519-714, especially 634-47. 


\section{ABSTRACTS}

This article considers the role of music in Pierre de Coubertin's aesthetic thought and practice, with particular focus on the concept of "eurhythmy", as expounded by writings published in the Revue Olympique in the early years of the Olympic movement. It argues that music - on account of its far-reaching and immediate emotional impact - should be considered the fundamental eurhythmic medium, and that, as a consequence of this centrality, Coubertin's sporting performances should be grasped not only as enthralling visual spectacles, but heard as resounding presentations of his modern Olympic humanism. Simultaneously, however, an acute problem of social class emerges, thus affording us insights into the politics of spectator sport in one of its most prominent early twentieth-century arenas. Since a significant part of music's impact is its powerful connotation of class, the musical choices Coubertin repeatedly made and dictated, and the hierarchy of taste they set out, point towards the inevitable sense of failure he felt when the Games took to the wider world stage in the hands of the national organising committees. The Berlin Summer Games of 1936 provide a closing case study of this trajectory: in some ways a culmination of Coubertin's eurhythmics, they can also be understood - in the year before his death - as the final realization of the limits of his aesthetic project.

\section{INDEX}

Mots-clés: Coubertin, music, Olympism, class, eurhythmy, modern spectacle, youth, Berlin 1936, fêtes sportives, Bourgault-Ducoudray, Ruskin, Carl Diem, Revue Olympique

\section{AUTHOR}

\section{NICHOLAS ATTFIELD}

Nicholas Attfield is a Lecturer in Music at the University of Birmingham. His research interests in European music, culture, and politics of the late nineteenth and early twentieth centuries are reflected in his DPhil on the reception of Anton Bruckner's symphonies, and by publications on Bruckner, Orff, Pfitzner, Debussy, and music criticism during the First World War. He has also been the recipient of British Academy, DAAD, AHRC, and Procter research awards. In 2017 his monograph Challenging the Modern: Conservative Revolution in German Music, 1918-1933 was published by Oxford University Press/British Academy. 